\title{
Poultry Manure and Poultry Waste Management: A Review
}

\author{
Richa $^{1}$, Vijay Kumar ${ }^{1}$, Jitender Singh ${ }^{2}$ and Nivedita Sharma ${ }^{3}$ \\ ${ }^{1}$ Department of Microbiology, Career Point University, Hamirpur (H.P), India \\ ${ }^{2}$ School of Pharmacy, Career Point University, Hamirpur (H.P)-176041 India \\ ${ }^{3}$ Department of Basic Sciences, University of Horticulture and Forestry \\ Nauni-Solan (H.P)-173230, India) \\ *Corresponding author
}

\begin{abstract}
A B S T R A C T
The best way to recycle poultry waste is to change it into biofertilizer. The poultry industries are increasing day by day due to its availability of lean meat which has low quantities of cholesterol. So, the increase in market of poultry products also causes the increase in growth of waste pollutions. Magnification in the demand of poultry products have led to fast and concentrated growth of the poultry industry, which deliver superabundant manure supplies. poultry waste is one of the best organic manure and also much valuable resource. At present the poultry farming supply vital sprig of animal protein and also the most freely reared livestock species amongst the all livestock species. In spite of its huge benefits like production of meat, eggs and job generations it frequently creates some environmental risks which are not good to both human and animal, because the poultry farming is the main cause of nasty smell, water ,soil, and air pollution. Whether the waste of poultry such as chicken feathers, chicken poop and hatchery wastes are not used in an appropriate form then they cause immense pollution. Being good sources of keratin proteins and amino acids the chicken feathers can be modified into useful products such as poultry manure which can be used as organic fertilizer, the other products which can be made by it are biodegradable plastic, feather meal and bio diesel. Out of all animal manures like vermicompost, horse, cow or steer manure, the nutritional value of poultry manure is high because it has highest amount of nitrogen, phosphorous \& potassium. Soil microorganisms have potential to convert poultry farming waste into ecofriendly clean fertilizer which increases the productions of agricultural products.
\end{abstract}

\section{Introduction}

The poultry industries are growing rapidly day by day and providing employment opportunities to people. But the problems also coming along with the poultry production that is the waste management that comes from poultry industries if this waste not treated well then it causes environmental pollutions that create problems to environment and humans.
Poultry waste can aspect the spread of diseases and also pollute the soil and groundwater resources if not properly handled.

So, magnify the demand of chicken meat has increase the production of organic waste. Organic wastes consist of varying amounts of organic matter, water, mineral nutrients (Edwards and Daniel, 1992; Brady and Weil, 
1996). As the utilization of organic wastes as manure has been in traditions for centuries world-wide (Straub, 1977) and also in the present times (Omiti et al., 1999; Clay et al., 2002; Gambara et al., 2002; Lopez-Masquera et al., 2008). Beside this, the requirement and utilization of chicken manure has overtaken the use of other animal manure (e.g. pig manure, kraal manure) because of its high nutritional value it has high content of nitrogen, phosphorus and potassium (Warman, 1986; Schjegel, 1992). An instance price of inorganic fertilizers has also emboldened the application of chicken manure (Place et al., 2003; Duncan, 2005). The poultry industry generates huge quantity of waste that includes solid wastes. The solid waste consists of feathers, feed, hatchery wastes, bedding material and excreta.

Even, chicken manure is prime between any other animal manure due to its high concentration of macro-nutrients (Warman, 1986; Duncan, 2005). Chicken manure offers a high percentage of nitrogen and phosphate. Currently the waste and manure produced by the poultry industries are used in agricultural land, when it used correctly. Yet, pollution and obstruction problems can occur when fertilizer is applied under environmental conditions which do not favors agronomic use of the manure borne nutrients (Sharpley et al., 1998; Casey et al., 2006; Kaiser et al., 2009). Chicken manure has great potential to recycle the agricultural land. Remunerative exercise from land application is based on their capacity to favorably change soil properties, such as soil $\mathrm{pH}$, nutrient availability to plant, cation exchange capacity organic matter content, capacity to hold water and soil tilts.

Poultry waste comprise all essential nutrient and also micronutrients it is also a good source of rare plant nutrients (Kelley et al., 1996; Williams et al., 1999; Chan et al., 2008; Harmel et al., 2009), especially for organic developer (Preusch et al., 2002). Adding of poultry manure to soils not only aid to overcome the disposal issue but also increase the physical, chemical and biological prolificity of soils (Friend et al., 2006; McGrath et al., 2009). Such as, sustained cultivation of tillable soils mostly results in the deterioration of soil structure which cause diminished crop production. But, if poultry manure is added to cultivated soil then it improve the fertility of soil by enhancing the organic matter of soil, increase water holding capacity, aggregate stability of the soil and improve oxygen diffusion rate (Mahimairaja et al., 1995a; Adeli et al., 2009). In spite of this addition, chicken manure enhances concentration of water soluble salts in soil. Chicken manure is also plentiful. There is no shortage of chicken, and they make manure on a surprisingly frequent basis. Many poultry houses have more than enough manure to go around and this manure can be stored for a long period of time. Chicken manure has all the right nutrients to keep soil high yielding and healthy too. The phosphorous in chicken poop becomes obtainable much slower than its nitrogen content. This will make it a reasonably slow releasing nutrient. Chicken manure contains less salt and free of the weed seeds that can appear in the waste of other animals. Lastly, because it is organic, you don't have to worry about any harsh chemicals entering the ground near plants if you are an organic gardener. Potassium is present in chicken manure. It's readily obtainable in most cases, but not as longlasting as the phosphorous. Here given below a chart which shows the nutritional value of poultry manure.

Best use of poultry manure by-products needs information of their composition not only for its profitable uses but also for environmental implications. To keep the perfection of environment is the main opinion when preparing and using poultry manure by- 
product as a nutrient resource in soil for agricultural and horticultural production (Sims and Wolf 1994; Moore et al., 1995; Moore Jr. et al., 2006). Mostly the environmental problems are concerned with unfair practices of land utility of poultry waste have centered on the contamination of ground and surface water with two main nutrients, $\mathrm{N}$ and $\mathrm{P}$ (Sims et al., 2005). Nevertheless, manure by-products may also have other possibly toxic trace elements, namely Copper $(\mathrm{Cu})$, Zinc $(\mathrm{Zn})$ and Arsenic (As) that are not noticed seriously till now (Bolan et al., 1992; Jackson et al., 2003; Epstein and Moss, 2006; Toor and Hunger, 2009) (Fig. 1-6).

\section{Composition of litter}

The raw form of substrate is collected from nearby poultry houses, which comprised mainly poultry litter. The major components of poultry waste include the feather, chicken poop, bedding material and the spilt feed (Kelley et al., 1996; Tasistro et al., 2004). The poultry waste contains nutrients, namely $\mathrm{N}, \mathrm{P}, \mathrm{K}$ and some trace elements, like as $\mathrm{Cu}$, $\mathrm{Zn}$ and As, also some microorganisms such as bacteria, fungi etc. Sawdust is added as improvement and bulking agent to lift up the carbon-to-nitrogen $(\mathrm{C}: \mathrm{N})$ ratio and the porousness of the feedstock. The formulation for the composting mixture was $65 \%$ broiler litter, $25 \%$ sawdust and $10 \%$ hog fuel on wet weight basis. Tap water was added to get initial moisture content of $55 \%$ for the mixture. During composting water provides the medium for chemical reactions to take place, for nutrients to be transported and for the microorganisms to move. The total amount of dry matter spit out by the birds can be estimated from the dry matter digestibility of the diet. Generally Broiler chickens digest approximately 85 to $90 \%$ of the dry substance of the feed (NRC, 1994). Broiler chickens ingest about 2.5 to $3.0 \mathrm{~kg}$ of dry matter up to
35 days of age and 5 to $6 \mathrm{~kg}$ of dry material up to 49 days of age. On the basis of the dried material digestibility of the feed $(87.5 \%)$, it is concluded that 0.34 and $0.63 \mathrm{~kg}$ of solid is spit out by a 35 and 49 day old bird, respectively (FSA, 2007). How much nutrient excreted can be calculated by the difference between amount of feed taken and amount digests by the chicken. It has been calculated that broiler chickens produce about $80 \%$ of the total K, $70 \%$ of the P and $55 \%$ of the total $\mathrm{N}$. The quantities of feed spilt during feeding can significantly alter the overall amount of solid and nutrients remaining in the litter or waste (Leytem et al., 2007). The poultry litter contains plant nutrients, like as $\mathrm{N}, \mathrm{P}$ and $\mathrm{K}$ and some trace elements, such as $\mathrm{Cu}, \mathrm{Zn}$ and As, pesticide residues, pharmaceuticals such as coccidiostats, endocrine disruptors and microorganisms.

\section{Characterization of litter}

Poultry litter referred as the bedding material used throughout the poultry production cycle. Materials used as litter include straw, sawdust, wood shavings, shredded paper and peanut or rice hulls. The collected manure is mixed with litter. Nitrogen lies in various forms and is constantly transformed by microorganism, and changes in temperature, moisture, $\mathrm{pH}$ and oxygen concentration. Poultry manure contains important concentrations of organic nitrogen because of presence of noble levels of protein and amino acids. The nitrogen in fresh manure, $60-80 \%$ is typically in organic form, viz. urea and protein. It depends on environmental conditions to convert organic nitrogen into ammonia. Ammonia exists as either gas $\left(\mathrm{NH}_{3}\right)$ or in an ionized form $\mathrm{NH}_{4}$, which is water-soluble. $\mathrm{NH}_{3}$ gas can be extinct to the atmosphere as $\mathrm{NH}_{4}$, can be transformed by microorganisms to nitrate the process is known as nitrification. Nitrate is highly mobile in water. When poultry manure is 
anaerobically digested then the concentration of endogenous ammonia-nitrogen increases considerably. Anaerobic microorganism colony can use ammonium ions, an excess of ammonium ion can prevent the destruction of organic compounds, the production of volatile fatty acids, and methanogenesis (Krylova et al., 1997). The presence of ammonium ions also contributes to a high $\mathrm{pH}$ that creates and disposal, storage and handling problems. The minimization of ammonia content is favored for any treatment of poultry waste.

\section{Need to reformation of poultry litter}

Neoteric poultry litter is hard to handle because of its high moisture content and foul smell. Next important problem of poultry litter is losing of $\mathrm{N}$ when it is store and dry during handling and in land application (Mahimairaja et al., 1994; Adeli et al., 2009). Nitrogen is lost in the form of ammonia during handling and also via nitrate leaching after application to land. Gaseous losses of $\mathrm{N}$ have great concern because it not only reduces the fertilizer value of poultry waste, but also cause atmospheric pollution, thus decay the environmental health. Intense use of fresh poultry litter also cause the stockpiling of ammonia in soils doing damage to seedlings and roots. So, the lousy management of this precious product could harm the crops and also generate pollution to surface and groundwater. Convenient technologies that are environment friendly and economically workable be expected for masterful management of poultry waste. But this can be get via rightful composting of poultry waste.

\section{Applications of poultry litter}

Poultry waste can be uses in a variety of ways. There are some applications of poultry litter.

\section{Fuel as a source of biogas}

The anaerobic digestion of poultry liter produce biogas which is a combustible gas composed of almost $60 \%$ methane, $38 \%$ carbon dioxide, small amounts of water vapors, ammonia and hydrogen sulphide. Biogas which is also known as 'producer' gas, used as a source of energy to provide cooking fuel and electric lighting in rural areas. The remains such as post anaerobic digested solid and burnt ash material utilize in the form of fertilizer and animal feed supplement (Liedl et al., 2006; Blake et al., 2007). Poultry waste can be ignited straight as a fuel source to produce heat energy. The only one main problem to use poultry waste is its approximately high moisture concentration. The moisture level of poultry waste should be less than $15 \%$ to obtain the maximal heat energy during combustion.

\section{Electricity production}

The burning of Poultry litter contributes the main attention as a method to yield heat and electricity at major facilities (Kelleher et al., 2002; Turnell et al., 2007; Fibrowatt, 2008). To make electric power from poultry liter, renewable 'green' sources there are a number of states in the US have turned to thermal modification of biomass. There is a best example that shows the best use of poultry waste to produce electricity, Minnesota generate above two million tons of broiler and turkey waste, the fuel for 'poultry power.' At present few Minnesota turkey farmers are doing work with a British company Fibrowatt that construct a manure-fired power plant in central Minnesota in 2007 (Fibrowatt, 2008). This plant burns almost half a million tons of poultry waste every year and produces 50 Megawatts of electricity that is ample enough to supply 40000 households. On the basis of the Fibrowatt experience, it is possible to produce electricity by burning poultry litter. 
Nevertheless, it is possible to utilize the litter as a fuel source to produce hot water, which will be useful for a poultry processing unit.

\section{As a good soil amendment}

Poultry compost is a good soil amendment because this poultry manure adds organic and inorganic plant nutrients and increase the water holding capacity \& beneficial biota in soil. Sustained cultivation of tillable soils and continuous use of urea or chemical fertilizers have harsh effect on soil, to regain or sustain soil fertility this poultry compost is the best option. Chemical fertilizer deteriorates the structure of soil that leads to detract the crop production. For example, in the Manawatu region of New Zealand, continuous cultivation of maize causes dilapidation of the natural situation of the soils. To see the result a plant growth experiment was operated in which the impact of poultry compost on the natural fertility of the cultivated soil and the growth of maize crop were examined. A soil that undergo continuous cultivation of maize almost for 34 years and a grazing soil were used in the study. Poultry manure was compared with urea at an application level of $300 \mathrm{~kg} \mathrm{~N} / \mathrm{ha}$ (Bolan et al., 1992). The addition of urea and poultry manure enhances the dry matter production of the maize crop in both cultivated and the grazing soils. In the pasture soil, there was no serious difference in dry matter production between the poultry compost and the urea treatments. In spite of this, in the case of the cultivated soil, poultry manure takes greater production than the urea treatment. By adding poultry manure similar dry matter production achieved in the cultivated soils and the pasture. The results informed that the reforming chemical fertility status of the cultivated soil only from chemical fertilizer input is not sufficient to achieve the maximum production of maize crop in these soils. These results reveal that the summation of poultry manure repair the physical fertility of the cultivated soil leading to enhanced maize growth. Compost products, such as poultry litter, are commonly used as a mulching material for horticultural and agricultural crops for conserving soil moisture and also to save the surface feeding roots from drying throughout the summer periods (Eneji et al., 2008; Agbede and Ojeniyi, 2009). Similarly the poultry litter also used to repair the biological fertility of mine tailings. Organic manures, such as the use of poultry waste, as an organic manure are increased for resettlement of disturbed land resulting from mining and any other industrial activities (Franzluebbers and Doraiswamy, 2007).

\section{As an animal feed}

Poultry manure singly or when mixed with feed grains, seem to be a significant feed for fish and cattle. Ruminants are capable to make use of the urea nitrogen of poultry manure (Smith and Fries, 1973). Yet, the existence of outward materials, namely plastic, glass, and feathers will affects the digestibility of poultry litter and so it is necessary to remove these debris from the waste before using it as a feed and it is also crucial to maintain low ash content. When soil is removed in large quantities from the litter, the ash content dramatically increased. It is recommended that if the ash content in poultry litter increased by $28 \%$ should not be fed to cattle (Williams et al., 1999). Unprocessed poultry waste contains large amount of pathogenic microorganisms like as Clostridium, Enterobacter spp and Salmonella. Therefore proper processing is required to lower the number of microbes and prepare a waste that would be free of pathogen (McCaskey and Anthony, 1979; Kawata et al., 2006). Pathogenic microorganisms can be destroyed by other methods such as chemical methods, fermentation, ensilation or heat processing (McCaskey and Martin, 1988; Cook et al., 
2008). Even though disease problems have not seen even if poultry manure feed to farm animals under admissible conditions but $\mathrm{Cu}$ toxicity has been found a major problem, specifically in sheep. Sheep are less tolerant than other livestock. $\mathrm{Cu}$ is scanty absorbed in the bird's digestive system so when an extra amount of $\mathrm{Cu}$ is added to poultry diets as a growth promoter, it is spit out in high concentration in the manure.

\section{Enhances soil fertility}

Generally Poultry waste believes the most valuable manures which are used as a fertilizer because of its low water content. As described sooner, poultry waste contains large amounts of N, P, K, salts and also trace elements. Poultry manure is also a good amendment for rice soils and maize soil. In Arkansas, rice production rises much as $286 \%$ by adding chicken manure (Miller et al., 1991).

\section{Crop production}

Poultry litter or poultry compost when added to soil the production of many crops such as rice, wheat, corn, and also many vegetables viz. spinach, cabbage. By adding poultry compost the yields of Bermuda grass, orchard grass also increases (Edwards and Daniel; Wood., 1992). Mostly the increase of production is due to $\mathrm{N}$.

\section{Composting}

The Composting is a simple and natural process. Composted poultry litter has very low odor. It is a more stable and more consistent material than fresh litter. Composting of poultry waste is an environment friendly method and can be an important way to protect our ground and surface waters from the excessive loading of litter nutrients. Poultry litter undergoes a number of handling method that includes insitu biological pond treatment, composting, and special chemical treatment. The most common application to overcome the problems related to handling and disposal of poultry manure is Aerobic composting. This process reduces the massiveness of the waste and produces a stable product that will be suitable for handling and land application. Composting also removes human and animal pathogens and it reduces the hazard of polluting groundwater. The use of suitable amendments with compost mostly reduces the nutrient losses. The amendments used for it are straw, paper waste, peat, woodchip and sulphur that helps to decrease the loss of $\mathrm{N}$ when composting of poultry waste. The cereal straw, which has easily decomposable carbon, has ability to reduce the $\mathrm{N}$ loss in Aerobic composting (Preusch et al., 2002). When poultry waste compost is prepared with phosphate rock and elemental sulphur then it form nutrient-rich eco-friendly compost. This compost can be used as a significant nutrient source particularly for organic farming practices. By adding small amount of elemental sulphur the $\mathrm{pH}$ of the compost will be reduce therefore it will reduce the volatilization loss of ammonia (Mahimairaja et al., 1993). By this the dissolution of rock phosphate increases and it enriches the compost with $\mathrm{P}$ and $\mathrm{S}$ nutrients (Mahimairaja et al., 1995b). Alum and zeolite are used to detract ammonia volatilization and also $\mathrm{P}$ solubility of poultry litter (Kithome et al., 1999; Delaune et al., 2004; Guo and Song, 2009). The possibility to use this types of amendments not only addresses environmental deed but also retouch the housing environments for the birds and workers by decreasing ammonia concentrations, and also by reforming the N:P ratio of the compost for crop exploitation. So it makes an economically viable choice for poultry developer (Moore et al., 1996; Sharpley et al., 2007). 


\section{Composting methods}

There are several methods through which compost the poultry litter. The composting methods range from fairly simple windrows to more sophisticated and capital intensive systems. That is designed to improve aeration in these systems and in-vessel systems used by specialty compost operations. With good management, the end products from different methods can be of a similar high quality.

\section{Windrow composting}

In windrow composting, poultry litter is placed in long windrows that are agitated or turned on a regular basis. The optimum height and width of these windrows will depend on the type of equipment used to turn them. Windrows can either be turned using bucket loaders or specialty windrow-turning machines. Depending on the bucket loader, a width of 10 to 20 feet and height of 6 to 12 feet is possible. Most specialty windrow turning machines require a height of between 3 and 9 feet. The frequency of the windrow turning will depend on factors such as the type of materials being composted and the porosity of the windrow. In most situations, windrows should be aerated on a weekly to two-week cycles depending on the temperature and moisture conditions in the compost.

\section{Passively aerated windrows or static piles}

Passively aerated systems are designed to eliminate the need for physical turning. Aeration is achieved through perforated plastic pipes embedded at 12- to 18- inch intervals in the base of each windrow. Air is drawn into the pipes from outside the pile and is forced through the pile from the chimney effect created by the hot gases escaping from the windrow. The size of these windrows is similar to other windrows. Compared to forced aeration systems, there is a much greater risk of odors using this type of system. Odors are reduced by covering the base and the outside of the windrows with at least a 6 inch cover of finished compost.

\section{Poultry compost vs. vermicompost}

The nutritional value of chicken compost is much more than that of vermicompost and its microbial load is also good. Vermicompost referred as the organic manures made by the activity of earthworms is commonly known as vermicompost. This vermicompost is mainly composted of cow dung, kitchen and vegetables waste. It is a good source of macro and micronutrients, growth hormones, vitamins, and microorganisms (Bhavalkar, 1991). As in nutritional value vermicompost consist of 2.0 to 2.5 per cent nitrogen, 1.0 to 1.5 per cent phosphorus and 1.0 to1.5 per cent potassium and also some essential micronutrients such as $\mathrm{Ca}, \mathrm{Mg}, \mathrm{Fe}, \mathrm{Cu}, \mathrm{Zn}$ and Mo (Jambhelkar (1994). Where as it is reported that the nutritional value of poultry manure is a rich source of nutrients for the crops as it contains 4.5-5.0\% N, 2.52.98\% $\mathrm{P}_{2} \mathrm{O}_{5}, 2.04-2.33 \% \quad \mathrm{~K}_{2} \mathrm{O}, 2.4-8.8 \% \mathrm{Ca}, 0.44-$ $0.67 \% \mathrm{Mg}, 0.13-0.15 \% \mathrm{~S}, 235-450 \mathrm{ppm} \mathrm{Zn}$, 98-150 ppm and $\mathrm{Cu}$ 150-450 ppm (Table 1).

The vermicompost developed from animal and agricultural waste had higher nutrient and microbial population. But beside this Poultry manure is one of the potential organic sources of nutrients than vermicompost. Nutrient composition may probably be attributed to the method of composting, the extent of decomposition, feeding materials of the birds, age of the birds and prevailing environmental conditions (Narahari1999). So, in brief the poultry compost are not only a good source of major essential micronutrients but are also known to enhance the physical properties of soils where as chemical fertilizer had harsh effect on soil. 
Table.1 Chemical composition of poultry manure (Sources; Research Gate)

\begin{tabular}{|l|c|}
\hline \multicolumn{1}{|c|}{ Nutrient element } & Value (\%) \\
\hline $\mathbf{N}$ & 4.50 \\
\hline $\mathbf{P}_{\mathbf{2}} \mathbf{O}_{\mathbf{5}}$ & 2.50 \\
\hline $\mathbf{K}_{\mathbf{2}} \mathbf{O}$ & 2.00 \\
\hline $\mathbf{C a O}$ & 2.00 \\
\hline $\mathbf{M g O}$ & 1.00 \\
\hline $\mathbf{S}$ & 0.50 \\
\hline $\mathbf{F e}$ & 0.04 \\
\hline $\mathbf{M n}$ & 0.09 \\
\hline $\mathbf{Z n}$ & 0.09 \\
\hline Other characteristics & 0.50 \\
\hline
\end{tabular}

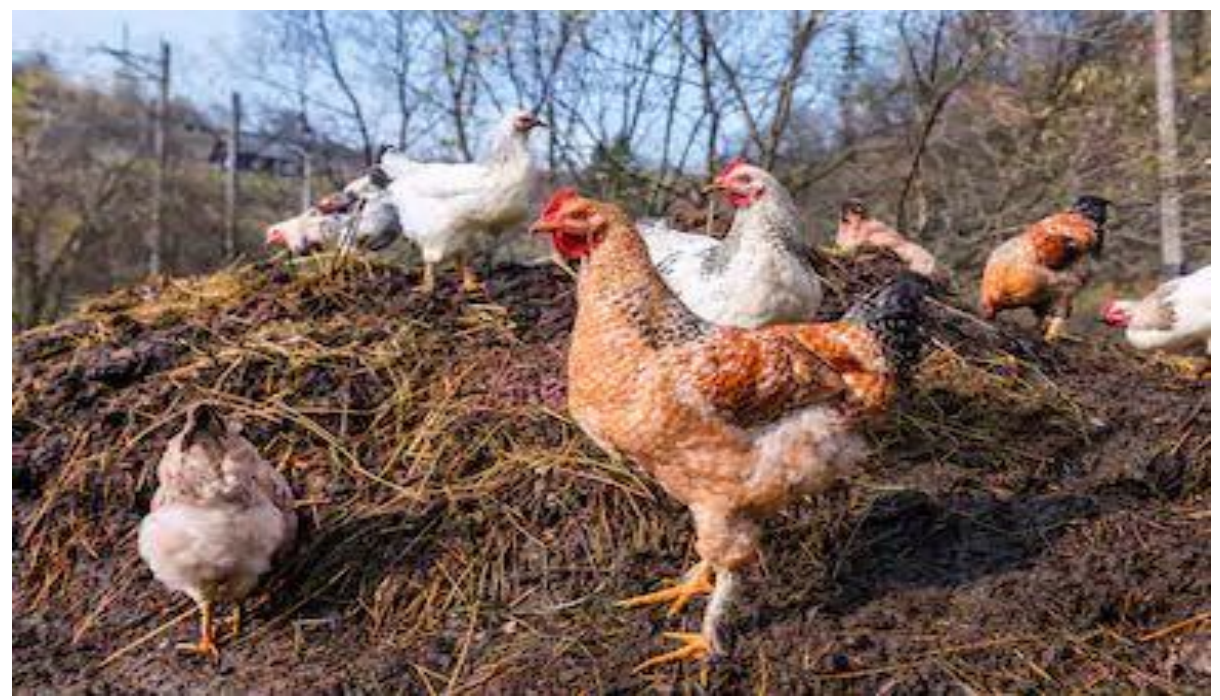

Figure.1 A heap of solid waste of poultry (Source; Thrifty fun)

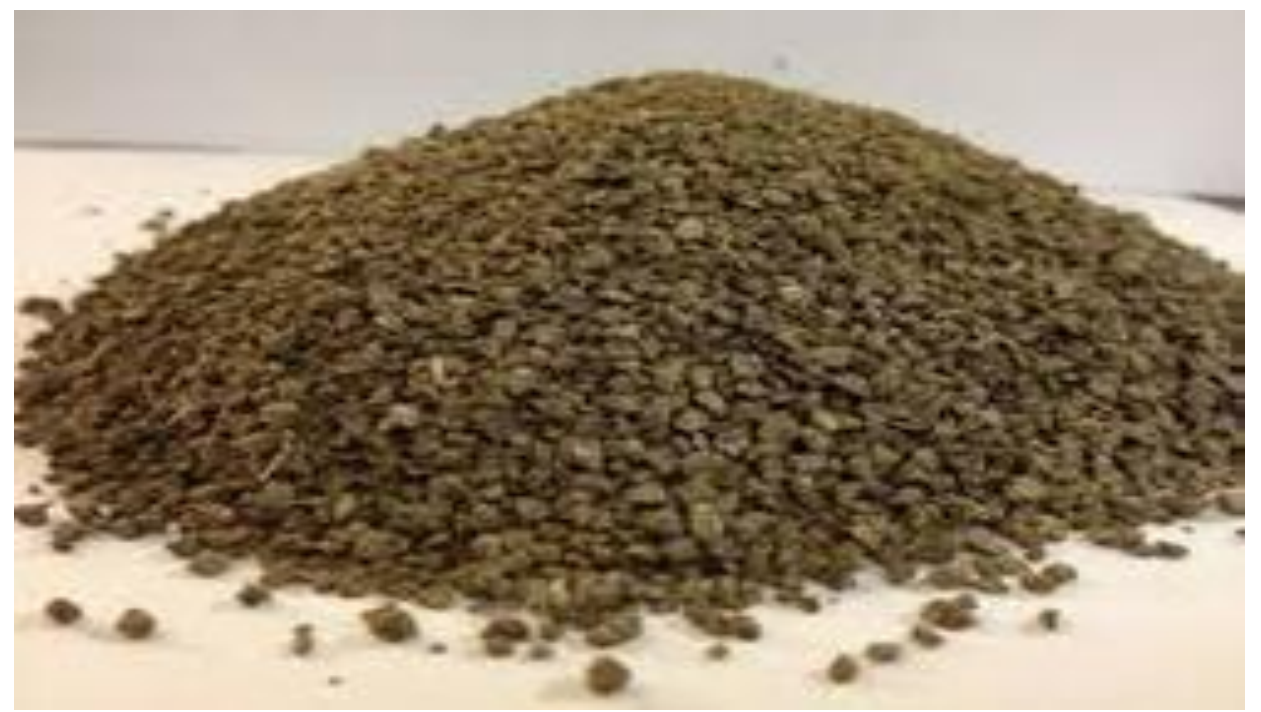

Figure.2 Final form of poultry compost (Source; India MART) 


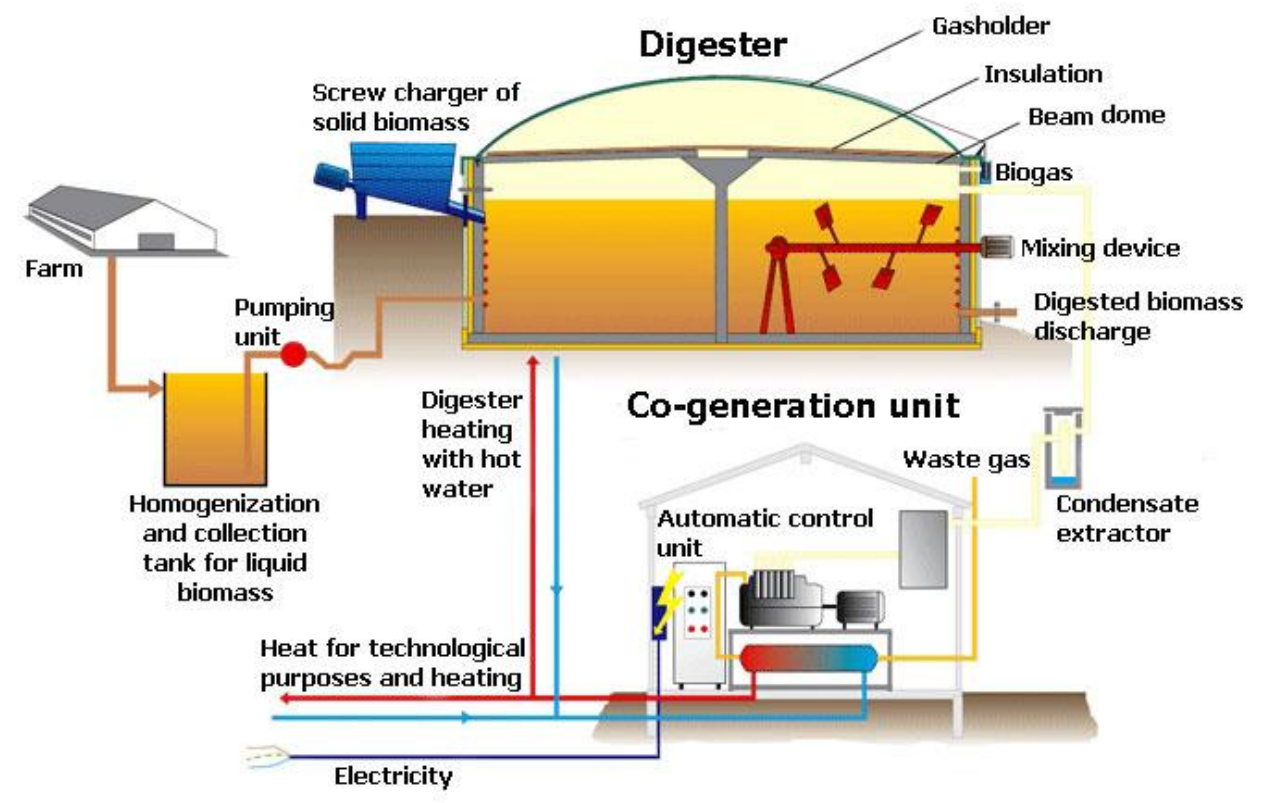

Figure.3 Use of poultry litter for the production of biogas (Source; budibadibu's blogwordpress.com)

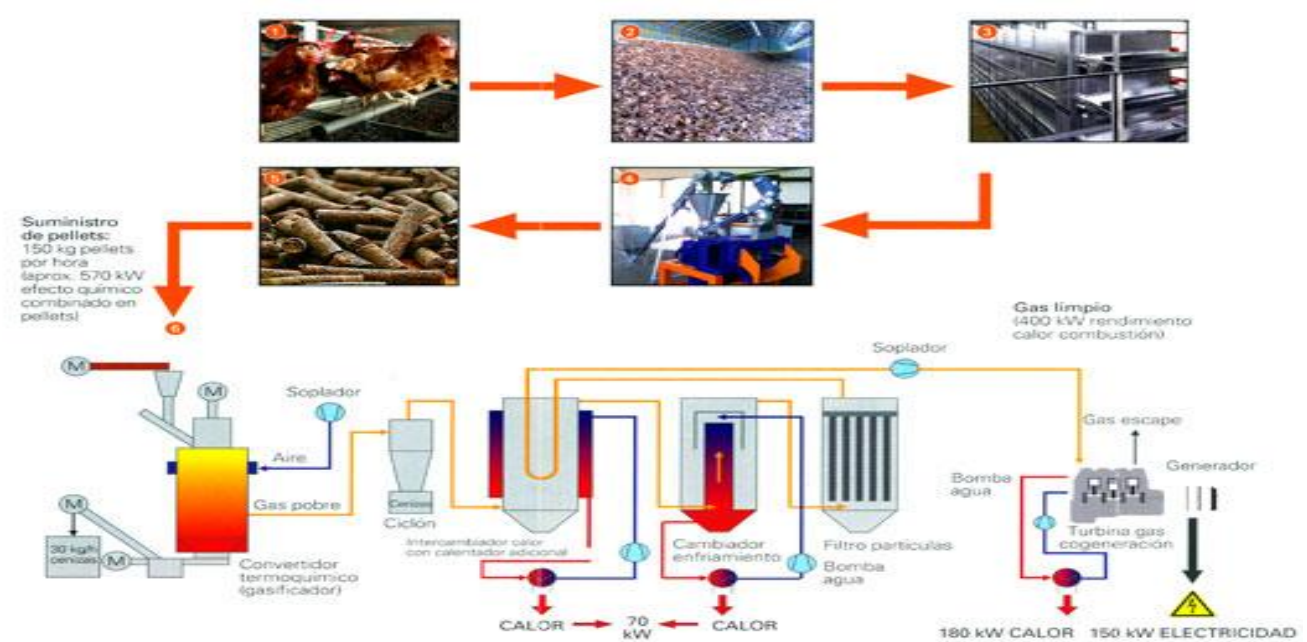

Figure.4 Poultry waste a good source to generate electricity (Source; Research Gate)

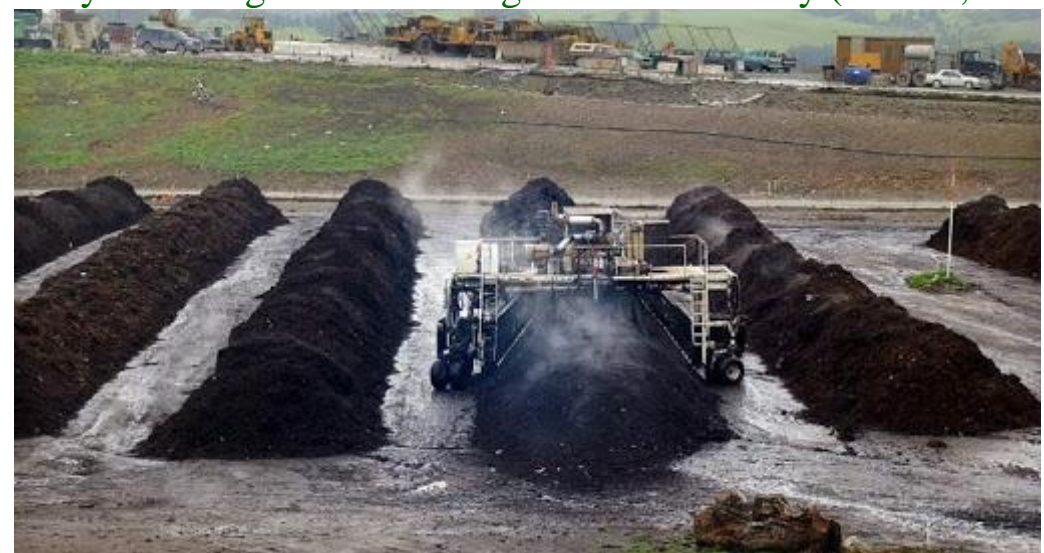

Figure.5 Windrow method of compost preparation (Source; User special) 


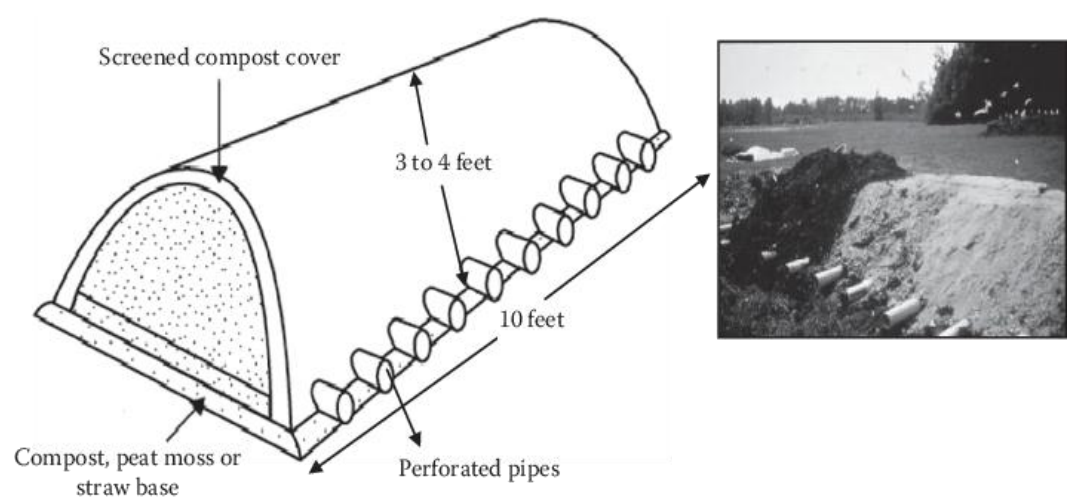

Figure.6 Passively aerated systems are designed to form poultry compost

(Source; Research gate)

The existence of bonny content of plant nutrients like $\mathrm{N}, \mathrm{P}, \mathrm{K}, \mathrm{Ca}, \mathrm{Mg}, \mathrm{S}, \mathrm{Fe}, \mathrm{Mn}, \mathrm{Cu}$, $\mathrm{Zn}$ and variant micro nutrients in poultry litter and their huge availability in India enlarges their potential role as optional nutrient sources and utilizes as fertilizers for improving soil health, plant health and productivity. The use of microbial consortia instead of single microbial inoculation proved better performance on crop growth and production. The study revealed that chicken manure is a potential source of plant nutrients and chemical conditioner. The use of poultry litter as a fuel has added extra benefit to mankind. Poultry litter is a good organic source of nutrients for raising crops, such as maize, wheat and rice. The achievement of utilization of poultry litter as a valuable nutrient source and soil amendment depend on developing technologies to produce homogenous value-added products. The compost made from poultry litter is eco friendly, inexpensive and suitable to overcome the dependence of chemical fertilizers. Composting of poultry waste has been proving to be prosperous and the end product can be vended commercially as an organic fertilizer. Poultry waste can be used as a good source of energy and nutrients.

\section{References}

Adeli, A., Tewolde, H., SistaniI, K.R., Rowe, D.E. 2009. Broiler litter fertilization and cropping system impacts on soil properties. Agronomy Journal .110: 1304-1310.

Agbede, T.M., Ojeniyi, S.O. 2009. Tillage and poultry manure effects on soil fertility and sorghum yield in southwestern Nigeria. Soil and tillage research. 104: 74-81.

Bhavalkar, U.S.1991. Vermiculture biotechnology for LEISA. Seminar on Low External Input Sustainable Agriculture, Amsterdam, Netherlands. Pp. 1-6.

Blake, J.P., Hess, J.B., Bock, B.R. 2007. Nutritional and economic value of poultry litter ash as a feed stock. Proceedings International Symposium on Air Quality and Waste Management for Agriculture Proceedings, Broomfield, CO., ASABE Pub. No. 701P0907cd.

Bolan, N.S., Mahimairaja, S., Hedley, M.J. 1992. Improving the fertilizer value of poultry manures. Proceedings of the Seminar on 'Eggs '92- winning in a deregulated environment,' Egg Producers Federation of New Zealand. 1-15.

Brady, N.C., Weil, R.R. 1996. The nature and properties of soils. 11th Edition. Prentice Hall International, Inc.

Casey, K.D., Bicudo, J.R., Schmidt, D.R., Singh, A., Gay, S.W., Gates, R.S., Jacobsen, L.D., Hoff, S.J. 2006. Air quality and emissions from livestock and poultry production/waste management systems, in: RICE, J.M., CALDWELL, D.F. \& HUMENIK, F.J. (Eds.) Animal Agriculture and the Environment: National Center for Manure and Animal Waste Management White Papers, Publication No 913C0306, pp. 1-40 (St. Joseph, MI, ASABE). 
Chan, K. Y., Vanzwieten, L., Meszars, L., Downie, A., Joseph, S. 2008. Using poultry litter biochars as soil amendments, Australian Journal of Soil Research. 46: 437-444.

Clay, D.C., Kelly, V., Mpyisi, E., Reardon, T. 2002. Input use and conservation investments among farm households in Rwanda: patterns and determinants. In Barrett Place and Aboud. (Eds.), Natural Resources Management in African Agriculture: Understanding and Improving Current Practices. Oxon and New York: CABI publishing. 103-114.

Cook, K.L., Rothrock, M.J., Warren, J.G., SistaniI, K.R., Moore, P.A. 2008. Effect of alum treatment on the concentration of total and ureolytic microorganisms in poultry litter. Journal of Environmental Quality. 37: 2360-2367.

Delaune, P.B., Moore, P.A., Daniel, T.C., Lemunyon, J.L. 2004. Effect of chemical and microbial amendment on ammonia volatilisation from composting poultry litter. Journal of Environmental Quality 33: $728-734$.

Duncan, J. 2005. Composting chicken manure. WSU Cooperative Extension, King County Master Gardener and Cooperative Extension Livestock Advisor.

Edwards, D.R., Daniel, T.C. 1992. Environmental impacts of on-farm poultry waste disposalA review. Bioresource Technology 41: 933.

Elemental concentrations of stored whole and fractionated broiler litter. Journal of Applied Poultry Research 5: 276-281.

Epstein, E., Moss, L.H. 2006. A comparison of characteristics of manures, biosolids, and mineral fertilizers. Journal of Residuals Science and Technology. 3: 35-42.

Fibrowatt .2008. Power from poultry litter. Available at: http://fibrowattusa.com.

Franzluebbers, A.J., Doraiswamy, P.C. 2007. Carbon sequestration and land degradation. Climate and land degradation in: International Workshop on Climate and Land Degradation: 343-358.

Friend, A.L., Roberts, S.D., Schoenholtz, S.H., Mobley, J.A., Gerard, P.D. 2006. Poultry litter application to Loblolly pine forests:
Growth and nutrient containment. Journal of Environmental Quality 35: 837-848.

from cropland and pasture fields fertilized with poultry litter. Journal of soil and water conservation 64: 400412.

FSA. 2007. Feedlot Services Australia Pty Ltd. Available at: http://www.fsaconsulting.net/.

Gambara, P., Machemedze, T., Mwenye, D. 2000. Chihota soil fertility Project, Annual Report 1998 to 1999. Unpublished report, AGRITEX, Marondera Zimbabwe.

Guo, M., Song, W. 2009. Nutrient value of alumtreated poultry litter for land application. Poultry science. 88: 1782-1792.

Harmel, R.D., Smith, D.R., Haney, R.L., and Dozier, M. 2009. Nitrogen and phosphorus run off

Jackson, B.P., Bertsch, P.M., Cabrera, M.L., Camberato, J.J., Seaman, J.C. , Wood, C.W. 2003. Trace element speciation in poultry litter. Journal of Environmental Quality 32: 535-540.

Jambhelkar, H. 1994. Bio-organic farming. Paper presented in the seminar on development of Agriculture, Andhra Pradesh. 16.

Kaiser, D.E., Mallarino, A.P., Haq, M.U. 2009. Runoff phosphorus loss immediately after poultry manure application as influenced by the application rate and tillage. Journal of Environmental Quality 38: 299-308.

Kawata, K., Nissato, K., Shiota, N., Hori, T., Asada, T., Oikawa, K. 2006. Variation in pesticide concentrations during composting of food waste and fowl droppings. Bulletin of environmental contamination and toxicology 77: 391-398.

Kelleher, B.P., Leahy, J.J., Henihan, A.M., O'Dwyer, T.F., Sutton, D., Leahy, M.J. 2002. Advances in poultry litter disposal technology - a review. Bioresource Technology 83: 27-36.

Kelley, T.R., Pancorbo, O.C., Merka, W.C., Thompson, S.A., Cabrera, M.L., Brnhat, H.M. 1996.

Kenya: Current practices, constraints and opportunities. CARMASAK Working Paper No. 1. KARI/ICRISAT, Kenya.

Kithome, M., Paul, J.W., Bomke, A.A. 1999. Reducing nitrogen losses during simulated composting of poultry manure using adsorbents or chemical amendments. 
Journal of Environmental Quality 28: 194201.

Krylova, N.I., Khabiboulline, R.E., Naumova, R.P., Nagle, M. 1997. The influence of ammonium and methods for removal during the anaerobic treatment of poultry manure. J. Chem. Technol. Biotechnol. 70: 99-105.

Leytem, A.B., Plumstead, P.W., Maguire, R.O., Kwanyuen, P., Brake, J. 2007. What aspect of dietary modification in broilers controls litter water-soluble phosphorus: dietary phosphorus, phytase, or calcium? Journal of Environmental quality. 36: 453-463.

Liedl, B.E., Bombardiere, J., Chatfield, J.M. 2006. Fertilizer potential of liquid and solid effluent from thermophilic anaerobic digestion of poultry waste. Water Science Technology. 53: 69-79.

Lopez- Masquera, M.E., Cabaleiro, F., Sainz, M.S., López- Fabal, A., Carral, E. 2008. Fertilizing value of broiler litter: Effects of drying and pelletizing. Bioresource Technol. 99: 5626-5633.

Mahimairaja, S., Bolan, N.S., and Hedley, M.J. 1995a. Agronomic effectiveness of poultry manure composts. Communications in Soil Science and Plant Analysis 26: 1843-1861.

Mahimairaja, S., Bolan, N.S., Hedley, M.J. 1993. Absorption of ammonia released from poultry

Mahimairaja, S., Bolan, N.S., Hedley, M.J. 1995b. Dissolution of phosphate rocks during the composting of poultry manure. Fertilizer Research 40: 93-104.

Mahimairaja, S., Bolan, N.S., Hedley, M.J., Macgregor, A.N. 1994. Transformation and loss of nitrogen in poultry manures during composting. Bioresource Technology. 47: 265-273.

manure onto soil and bark and the use of absorbed ammonia in the dissolution of phosphate rock. Compost Science and Utilisation 1: 10-21.

Mccaskey, T.A., Anthony, W.B. 1979. Human and animal health aspects of feeding live stock excreta. Journal of Animal Science. 48: 163-177.

Mccaskey, T.A., Martin jr, J.B. 1988. Evaluation of a process for improved quality and microbiological safety of broiler litter. Biological Wastes. 25: 209-218.
Mcgrath, S., Maguire, R.O., Tacy, B.F., Kike, J.H. 2009. Improving soil nutrition with poultry litter application in low input forage systems. Agronomy Journal. 102: 48-54.

Miller, R.E., Lei, X., Ullrey, D.E. 1991. Trace elements in animal nutrition, in: MORTVEDT, J.J.(Ed.) Micronutrients in Agriculture. 2: 593- 662. (Madison, WI, Soil Science Society of America).

Moore Jr, P.A., Joern, B.C., Edwards, D.R., Wood, C.W., Daniel, T.C. 2006. Effects of manure amendments on environmental and production problems, in: RICE, J.M., CALDWELL , D.F., \& HUMENIK, F.J. (Eds) Animal Agriculture and the Environment: National Center for Manure and Animal Waste Management White Papers. 913C0306: 1-40. (St. Joseph, MI, ASABE).

Moore, P.A., Daniel, T.C., Edwards, D.R., Miller, D.M. 1996. Evaluation of chemical amendments to reduce ammonia volatilisation from poultry litter. Poultry Science. 75: 315-320.

Moore, P.A., Daniel, T.C., Sharpley, A.N., Wood, C.W. 1995. Poultry manure management environmentally sound options. Journal of Soil and Water Conservation.50: 321-327.

Narahari, D. 1999. Fertilizer value of poultry excreta. Agro. India. 4: 4-5.

NRC., 1994. Nutrient Requirements of Poultry: Ninth Revised Edition. National Research Council. Washington, D.C., National Academy Press.

Omiti, J.M., Freeman, H.A., Kaguongo, W., Bett, C. 1999. Soil fertility maintenance in Eastern

Place, F., Barrett, C.B., Ade, Freeman, H., Ramisch, J.J., Vanlauwe, B. 2003. Prospects for integrated soil fertility management using organic and inorganic inputs: Evidence from smallholder African Agricultural Systems. Food Policy 28: 365378.

Preusch, P.L., Adler, P.R., Sikora, L.J., Tworkoski, T.J. 2002. Nitrogen and phosphorus availability in composted and uncomposted poultry litter. Journal of Environmental Quality. 31: 2051-2057.

Schjegel, A.J. 1992. Effect of composted manure on soil chemical properties and nitrogen use 
by grain sorghum. J. Prod. Agric. 5: 153157.

Sharpley, A., Meisinger, J.J., Breeuwsma, A., Sims, J.T., Daniel, T.C., Schepers, J. S. 1998. Impact of animal manure management on ground and surface water quality, in: HATFIELD, J.L. \& STEWART, B.A. (Eds) Animal Waste Utilisation. Effective Use of Manure as Soil Resource. 173-242 (Chelsea, MI, Ann Arbor Press).

Sharpley, A.N., Herron, S., Daniel, T. 2007. Overcoming the challenges of phosphorusbased management challenges in poultry farming. Journal of Soil and Water Conservation. 58: 30-38.

Sims, J.T., Bergstrom, L., Bowman, B.T., Oenema, O. 2005. Nutrient management for intensive animal agriculture policies and practices for sustainability. Soil Use and Management. 21: 141-151.

Sims, J.T., Wolf, D.C. 1994. Poultry Waste Management: Agricultural and Environmental Issues. Advances in Agronomy. 52: 1-83.

Singer, R.S., Hofacre, C.L. 2006. Potential impacts of antibiotic use in poultry production. Avian Diseases. 50: 161-172.

Smith, L.W., Fries, G.F. 1973. Dehydrated poultry manure as a crude protein supplement for lactating cows. Journal of Dairy Science.
56: 668-672.

Straub, D. 1977. A hot issue-chicken manure. Tilth producers quarterly. A Journal of Organic and Sustainable Agriculture. United States Department of Agriculture (USDA) .1995. Laboratory methods for soil and foliar analyses in long-term environment monitory programs. EPA/600/R-95/077.

Tasistro, A.S., Kissel, D.E., Bush, P.B. 2004. Spatial variability of broiler litter composition in a chicken house. Journal of applied poultry research. 13: 29-43.

Toor, G.S., Hunger, B.E. 2009. Phosphorus and trace metal dynamics in soils amended with poultry litter and granulates. Soil Use and Management. 25: 409-418.

Turnell, J.R., Faulkner, R.D., Hinch, G.N. 2007. Recent advances in Australian broiler litter utilisation. World's Poultry Science Journal. 63: 223-231.

Warman, P.R. 1986. The effect of fertilizer, chicken manure and dairy manure on Timothy yield. Tissue composition and soil fertility. Agric. Wastes. 18: 289-298.

Williams, C.M., Barker, J.C., Sims, J.T. 1999. Management and utilisation of poultry wastes. Reviews of Environmental Contamination and Toxicology. 162: 105157.

\section{How to cite this article:}

Richa, Vijay Kumar, Jitender Singh and Nivedita Sharma. 2020. Poultry Manure and Poultry Waste Management: A Review. Int.J.Curr.Microbiol.App.Sci. 9(06): 3483-3495. doi: https://doi.org/10.20546/ijcmas.2020.906.410 